\title{
KESADARAN MASYARAKAT BEROLAHRAGA UNTUK PENINGKATAN KESEHATAN DAN PEMBANGUNAN NASIONAL
}

\section{Oleh: Yudik Prasetyo \\ Dosen Jurusan Pendidikan Kesehatan dan Rekreasi FIK UNY}

\begin{abstract}
Abstrak
Olahraga pada dasarnya merupakan kebutuhan setiap manusia di dalam kehidupan, agar kondisi fisik dan kesehatannya tetap terjaga dengan baik. Olahraga dapat meningkatkan kesehatan dan mencegah timbulnya penyakit termasuk penyakit jantung, diabetes tipe 2, osteoporosis, bentuk kanker, obesitas, dan cedera. Partisipasi dalam olahraga juga dikenal untuk mengurangi depresi, stres dan kecemasan, meningkatkan kepercayaan diri, tingkat energi, kualitas tidur, dan kemampuan untuk berkonsentrasi.

Ada tiga faktor yang berdampak pada partisipasi olahraga, yaitu faktor individu, faktor lingkungan, dan faktor sosial budaya. Partisipasi masyarakat dalam melakukan kegiatan olahraga semakin meningkat yang ditunjukkan dengan peningkatan partisipasi masyarakat pada indeks pembangunan olahraga (SDI). Olahraga yang secara spesifik dapat meningkatkan derajat kesehatan bagi pelakunya adalah olahraga kesehatan. Dalam olahraga kesehatan tidak hanya melatih aspek jasmaniah, juga menjangkau aspek rohaniah dan aspek sosial. Kesadaran masyarakat untuk berolahraga memberikan kontribusi dalam pembangunan individu dan masyarakat yang cerdas, sehat, terampil, tangguh, kompetitif, sejahtera, dan bermartabat.
\end{abstract}

Kata Kunci: kesadaran, olahraga, pembangunan

Kesehatan sangat penting bagi manusia, karena tanpa kesehatan yang baik, setiap manusia akan sulit dalam melaksanakan aktivitasnya sehari-hari. Semakin padatnya aktivitas yang dilakukan seseorang menjadikan mengabaikan masalah berolahraga. Tidak adanya waktu luang karena kesibukan di kantor, di kampus, di perusahaan, mengakibatkan seseorang tersita waktu kesempatan untuk berolahraga. Olahraga pada dasarnya merupakan kebutuhan setiap manusia di dalam kehidupan, agar kondisi fisik dan kesehatannya tetap terjaga dengan baik. Oleh karena itu, manusia ingin berusaha menjaga kesehatannya dan salah satu cara agar kesehatan tetap terjaga dengan baik adalah melalui olahraga.

Dalam kehidupan sehari-hari agar dapat menunjang kesehatan, perlu adanya tindakan atau upaya yang dilakukan. Upaya kesehatan adalah setiap kegiatan untuk memelihara dan 
meningkatkan kesehatan yang bertujuan untuk mewujudkan derajat kesehatan yang optimal bagi masyarakat. Upaya kesehatan diselenggarakan dengan pendekatan pemeliharaan, peningkatan kesehatan (promotif), pencegahan penyakit (preventif), penyembuhan penyakit (kuratif), dan pemulihan kesehatan (rehabilitatif), yang dilaksanakan secara menyeluruh, terpadu, dan berkesinambungan. Hal ini akan terwujud tentunya tidak hanya dari pemangku kebijakan olahraga yang menggerakkan, tetapi bagaimana tingkat kesadaran masyarakat dalam berpartisipasi olahraga.

Perkembangan zaman yang semakin maju, maka partisipasi masyarakat dalam pembangunan olahraga akan menentukan postur dan kemajuan pembangunan olahraga sampai ke suatu daerah. Pembangunan olahraga yang bertumpu pada peran serta masyarakat dahulu telah dicoba dalam kemasan "gerakan memasyarakatkan olahraga dan mengolahragakan masyarakat". Artinya seluruh warga masyarakat mengenal dan menggemari berbagai jenis olahraga serta membiasakan diri untuk berolahraga. Meningkatkan partisipasi segenap lapisan masyarakat, sehingga menjadi bagian dari kebiasaaan. Dengan demikian, tercipta masyarakat yang (1) sehat jasmani dan rohani,(2) terbentuk kepribadian, yang antara lain berani, berdisiplin, jujur, dan cinta tanah air, bangsa, dan negara, (3) berkembang tingkat pengetahuan dan kecerdasan, dan (4)berkembang rasa sosial. (Direktorat Keolahragaan, 1987: 5).

Masyarakat Indonesia saat ini masih kurang menyadari akan pentingnya hidup sehat. Hal ini terjadi karena kurangnya animo/minat dan apresiasi masyarakat terhadap olahraga. Hasil Susenas menunjukkan bahwa partisipasi penduduk berumur 10 tahun ke atas dalam melakukan olahraga mengalami penurunan dari waktu ke waktu. Peningkatan partisipasi olahraga hanya terjadi dari tahun 2000 sebesar 22,6 persen menuju tahun 2003 menjadi sebesar 25,4 persen. Dalam kurun waktu 2003, 2006, dan 2009 partisipasi penduduk dalam melakukan olahraga terus menurun, yaitu dari 25,4 persen pada tahun 2003, turun menjadi 23,2 persen pada tahun 2006, dan terakhir turun menjadi 21,8 persen pada tahun 2009. Pola tersebut berlaku baik di daerah perkotaan maupun perdesaan. Partisipasi berolahraga penduduk perkotaan lebih tinggi apabila dibandingkan dengan penduduk perdesaan. Kondisi ini didukung oleh fasilitas dan jenis olahraga yang berkembang di perkotaan lebih banyak dibandingkan di perdesaan (Sekretaris Kemenpora, 2010: 18). 
Aktivitas fisik dapat meningkatkan kesehatan dan mencegah timbulnya penyakit termasuk penyakit jantung, diabetes tipe 2, dan osteoporosis, bentuk kanker, obesitas, dan cedera. Partisipasi dalam aktivitas fisik juga dikenal untuk mengurangi depresi, stres dan kecemasan, dan meningkatkan kepercayaan diri, tingkat energi, kualitas tidur, dan kemampuan untuk berkonsentrasi (VicHealth, 2010: 1). Secara fisiologis, olahraga dapat dijadikan wahana pemberdayaan kemampuan fungsi fisiologis seperti meningkatkan kesehatan, kebugaran, dan meningkatkan kualitas komponen kondisi fisik seperti kerja jantung dan paru-paru, kelincahan, kecepatan, dan kekuatan.

Secara sosial, olahraga dapat digunakan sebagai media sosialisasi melalui interaksi dan komunikasi dengan orang lain atau lingkungan sekitar. Salah satu indikasi meningkatnya keinginan masyarakat akan derajat kesehatan yang tinggi, penampilan jasmani yang proporsional dan aktualisasi diri yang lebih luas dalam lingkungannya mencerminkan bahwa kebutuhan masyarakat semakin beragam sehingga membutuhkan tempat atau wahana yang dapat menyalurkan serta memenuhi kebutuhan tersebut (Zulkarnaen, 2010: 2).

\section{Pentingnya Kesadaran Masyarakat dalam Berolahraga untuk Peningkatan Kesehatan}

“All road leads to Rome, banyak jalan menuju ke Roma, (Italia). Pepatah itu mungkin sering didengar untuk berbagai maksud dan tujuan, terutama ketika memberikan motivasi untuk seseorang agar tujuannya tercapai dan percaya akan kemampuan. Hal ini juga bisa diasumsikan bahwa untuk mencapai tingkat kesehatan bisa dengan berbagai macam cara, salah satunya adalah dengan melakukan olahraga secara kontinu, bisa dengan olahraga di rumah dengan exercise, treadmill, bersepeda, berenang atau dengan berlari-lari di sekeliling rumah.

Kemalasan dalam melakukan atau menyelesaikan sesuatu adalah hal yang sering dialami oleh semua orang. Dalam berolahraga, malas adalah hal yang cukup sering ditemui. Hal ini biasanya disebabkan oleh 2 dua hal, yaitu pertama, ketakutan akan sakit setelah melakukan olahraga. Rasa pegal yang muncul 1-2 hari sesudah latihan biasanya merupakan suatu pengalaman yang membuat jera, sehingga orang berpikir dua kali kalau diajak untuk kembali berolahraga. Sesi latihan dengan intensitas yang terlalu tinggi yang melebihi 
kapasitas tubuh adalah menjadi penyebabnya, ibarat bayi yang masih merangkak harus dipaksa berlari. Кedua, kurangnya kesadaran terhadap pentingnya kesehatan dan kebugaran. Orang yang tidak merasa perlunya menjadi pintar biasanya memang tidak rajin belajar. Sama juga dengan orang yang tidak menyadari pentingnya kebersihan biasanya akan malas untuk mandi. Demikian juga, orang yang kurang menyadari pentingnya hidup sehat dan bugar akan malas untuk berolahraga (Ade Truna, 2010: 53).

Di negara Australia, ada beberapa faktor yang berdampak pada partisipasi dalam aktivitas fisik, yaitu sebagai berikut:

\section{Faktor Individu}

Hambatan untuk aktivitas fisik dikarenakan kurangnya waktu (40\%), dan cedera atau cacat $(20 \%)$.

\section{Faktor lingkungan}

Lingkungan yang dibangun hendaknya dapat mendukung aktivitas fisik. Beberapa bangunan didirikan di Australia tetapi masih kurang memperhatikan aspek dari aktivitas fisik. Pertimbangan seharusnya diberikan kepada aspek pembangunan yang memiliki dampak signifikan pada tingkat aktivitas fisik, termasuk penyediaan jalan setapak, jalan konektivitas, dan ruang hijau yang dapat dimanfaatkan untuk berolahraga.

\section{Faktor Sosial dan Budaya}

Biaya berpartisipasi dalam aktivitas fisik menjadi salah satu faktor penghambat bagi sebagian keluarga. Hal ini dibuktikan dengan korelasi kuat antara partisipasi olahraga dan pendapatan keluarga di Australia. Selain itu, terlihat sekali bahwa masyarakat yang sudah membudayakan olahraga akan lebih optimal dalam pekerjaan maupun melangsungkan hidupnya.

(VicHealth, 2010: 5).

Pada saat melihat di negara tetangga seperti Thailand, The National Statistic Thailand menemukan bahwa kurang dari $30 \%$ masyarakat Thailand secara teratur terlibat dalam aktivitas fisik, namun fakta paling mengkhawatirkan saat ini adalah sangat tinggi prevalensi kegemukan antara anak-anak yang berusia antara 2-18 tahun. Alasan umum untuk tidak aktif, misalnya kurangnya waktu, olahraga dan peralatan menunjukkan temuan-temuan yang bertentangan dengan negara Thailand, karena hampir seluruh (76 Provinsi) di 
Thailand memiliki taman olahraga standar dan taman umum. Database yang tersedia menunjukkan bahwa hanya satu-sepertiga dari stadion/taman 50,768 dan 12,880 kecil taman umum yang saat ini digunakan. Oleh karena itu, yayasan promosi kesehatan Thailand (Thai Health) memulai rencana induk untuk memromosikan kegiatan fisik dan olahraga untuk kesehatan agar lebih baik di tingkat individu dan masyarakat (Thai Health Promotion Foundation, ).

Berdasarkan penelitian yang dilakukan oleh Fonterra dalam rangka menyambut hari osteoporosis dunia menunjukkan bahwa Indonesia adalah negara di Asia Tenggara yang paling tidak aktif dengan 68 persen respondennya menyatakan mereka berolahraga kurang dari tiga kali seminggu. Posisi kedua ditempati Singapura dengan jumlah responden 66 persen yang berolahraga kurang dari tiga kali seminggu. Posisi ketiga ditempati Malaysia dengan jumlah responden 59 persen. Sementara itu, negara yang menduduki peringkat terbaik dalam berolahraga adalah Vietnam dan Filipina dengan jumlah 60 persen dan 46 persen responden mengatakan mereka olahraga minimal tiga kali seminggu (health.detik.com).

Olahraga merupakan bagian yang tidak terpisahkan dalam kehidupan sehari-hari masyarakat. Melalui olahraga dapat dilakukan national character building suatu bangsa, sehingga olahraga menjadi sarana strategis untuk membangun kepercayaan diri, identitas bangsa, dan kebanggaan nasional. Partisipasi masyarakat dalam melakukan kegiatan olahraga semakin meningkat yang ditunjukkan dengan peningkatan partisipasi masyarakat pada indeks pembangunan olahraga (SDI) dari 0,345 pada tahun 2005 menjadi 0,422 pada tahun 2006. Pengukuran SDI sesungguhnya meliputi perkembangan banyaknya anggota masyarakat suatu wilayah yang melakukan kegiatan olahraga, luasnya tempat yang diperuntukkan untuk kegiatan berolahraga bagi masyarakat dalam bentuk lahan, bangunan, atau ruang terbuka yang digunakan untuk kegiatan berolahraga dan dapat diakses oleh masyarakat luas. Kebugaran jasmani yang merujuk pada kesanggupan tubuh untuk melakukan aktivitas tanpa mengalami kelelahan yang berarti, serta jumlah pelatih olahraga, guru Pendidikan Jasmani dan Kesehatan (Penjaskes), dan instruktur olahraga dalam suatu wilayah tertentu (Menpora RI, 2010: 7). 
Selain itu, pemerintah juga berupaya dengan menyiapkan fasilitas berolahraga yang dapat dimanfaatkan untuk masyarakat umum, upaya tersebut dapat menjadi daya tarik tersendiri dan berdampak langsung pada adanya kepedulian dan partisipasi masyarakat untuk berolahraga secara teratur. Olahraga rutin sudah menjadi sebuah kebutuhan sebagai pola hidup sehat bagi masyarakat, hal tersebut dapat dilihat seperti adanya senam pagi, jalan sehat, fitnes, futsal, voli, sepak bola, sepeda santai yang juga sering digelar untuk masyarakat. Dengan meningkatnya partisipasi masyarakat dalam menjalankan aktifitas olahraga, terjadi peningkatan derajat kesehatan dan kebugaran masyarakat dari tahun ke tahun.

Olahraga apabila sudah tumbuh dan berkembang serta membudaya pada masyarakat, pada tahap berikutnya olahraga akan menjadi kebutuhan bagi masyarakat. Dengan demikian, masyarakat yang sadar akan olahraga, tidak perlu lagi dipaksa atau disuruh untuk melakukan olahraga. Meskipun demikian, yang terjadi, pada keadaan masyarakat di Indonesia belum secara menyeluruh sampai kepada taraf ini (sadar dan butuh olahraga). Jika masyarakat telah menganggap olahraga sebagai kebutuhan, masyarakat akan lebih banyak belajar tentang olahraga, bagaimanakah olahraga yang benar untuk tujuan kesehatan, sehingga dapat meningkatkan derajat kesehatannya.

Olahraga yang secara spesifik dapat meningkatkan derajat kesehatan bagi pelakunya adalah olahraga kesehatan. Olahraga kesehatan sangat berkaitan langsung dengan masyarakat, karena pada dasarnya olahraga kesehatan melibatkan masyarakat secara merata tanpa melihat tingkatan umur, gender, lapisan masyarakat tertentu. Selain itu, olahraga kesehatan juga mencirikan $5 \mathrm{M}$ dalam pelaksanaannya yaitu: massal, mudah, meriah, murah, dan manfaat. Olahraga kesehatan mampu memelihara dan meningkatkan kemampuan fungsional jasmaniah para pesertanya dengan pembebanan yang dapat diatur secara bertahap dalam dosis yang adekuat.

Dalam olahraga kesehatan tidak hanya melatih aspek jasmaniah serta dapat juga menjangkau aspek rohaniah dan aspek sosial. Hal ini terlihat dari jumlah pesertanya yang massal dengan suasana yang informal, menimbulkan rasa gembira yang akan memberikan pengaruh positif terhadap rohani dan mendorong terjadinya pergaulan yang lepas dari 
hambatan-hambatan yang bersumber pada perbedaan kedudukan sosial dan tingkat ekonomi.

\section{Peran Olahraga dalam Pembangunan Nasional}

Pembangunan merupakan suatu upaya terprogram yang dilaksanakan secara terus menerus guna mempertahankan dan meningkatkan taraf hidup manusia baik lahir maupun bathin. Pada hakikamya tujuan pembangunan di Indonesia adalah untuk membangun manusia seutuhnya, dan untuk mewujudkan suatu masyarakat adil dan makmur yang merata baik material maupun spritual berdasarkan Pancasila dan Undang-Undang Dasar 1945. Pembangunan nasional itu meliputi seluruh aspek kehidupan bermasyarakat, berbangsa dan bernegara serta keberhasilan untuk mencapai tujuan tersebut mensyaratkan adanya peran serta segenap lapisan masyarakat yang memiliki tanggung jawab penuh terhadap kemajuan bangsa dan negara.

Pada hakikatnya pembangunan olahraga tidak dapat dipisahkan dari kehidupan dan sekaligus merupakan kebutuhan manusia. Oleh karena itu, pembangunan olahraga merupakan bagian yang tidak dapat dipisahkan dari pembinaan dan pembangunan bangsa dalam rangka peningkatan kualitas sumber daya insani, terutama diarahkan pada peningkatan kesehatan jasmani dan rohani, serta ditujuan untuk membentuk watak dan kepribadian yang memiliki displin dan sportivitas yang tinggi. Di samping itu, pembangunan olahraga juga dijadikan sebagai alat untuk memperlihatkan eksistensi bangsa melalui pembinaan prestasi yang setinggi-tingginya (Kusnan, 2013: 48).

Kesadaran masyarakat untuk berolahraga memberikan kontribusi dalam pembangunan individu dan masyarakat yang cerdas, sehat, terampil, tangguh, kompetitif, sejahtera, dan bermartabat. Hal tersebut mengandung makna bahwa kedudukan olahraga amat penting dan strategis dalam posisinya, karena memiliki kompetensi yang tinggi dalam memengaruhi keberhasilan pembangunan sektor lainnya terutama yang berkaitan dengan peningkatan kualitas sumber daya manusia dan kehidupan masyarakatnya (Farhan, 2011: 82).

Di tengah keprihatinan bangsa Indonesia yang menghadapi krisis di berbagai aspek kehidupan bermasyarakat, berbangsa, dan bernegara, terutama yang menyangkut moral, kegiatan olahraga menjadi salah satu solusi alternatif yang sangat penting dan menentukan 
dalam kerangka membangun opini publik bagi peletakan sendi-sendi dasar dan sistem pencerahan masyarakat dalam arti yang sangat luas. Melalui pembangunan dan pengembangan olahraga tidak saja dapat mengangkat harkat dan martabat bangsa melalui pergaulan internasional, melainkan juga sebagai salah satu media yang dapat menggerakkan ekonomi kerakyatan serta industri olahraga, menanamkan nilai kebersamaan, jati diri, dan perdamaian antarbangsa sebagai perwujudan Nation And Character Building.

Untuk melaksanakan pembangunan olahraga, perlu dilakukan berbagai upaya penggalangan dan penggalian terhadap potensi yang ada, baik dalam bidang sistem pembinaan, lembaga/organisasi, maupun adanya landasan hukum yang digunakan sebagai dasar pembangunan keolahragaan. Untuk mewujudkan tercapainya tujuan tersebut, pembangunan olahraga harus dijadikan sebagai gerakan nasional. Gerakan nasional ini perlu terus dibangun dan ditingkatkan agar lebih meluas dan merata di seluruh tanah air untuk menumbuhkan dan menciptakan budaya olahraga yang sehat. Perlunya penyediaan sarana dan prasarana olahraga yang memadai baik di lingkungan sekolah, pekerjaan maupun pemukiman sehingga memungkinkan segenap lapisan warga masyarakat melakukan olahraga dan berbagai aktivitas jasmani.

Peran olahraga dalam mendukung terciptanya sumber daya manusia yang memiliki kualitas fisik yang baik sudah tidak diragukan lagi. Selain bermanfaat untuk jasmani, olahraga juga berperan dalam pengembangan karakter bangsa. Olahraga mampu melahirkan kebiasaan yang baik seperti jujur, disiplin, sportif, tanggung jawab, dan kerja sama (Siti Kosasih, 2013: 1). Olahraga sangat berperan untuk manusia, dan olahraga selalu dibutuhkan sepanjang zaman. 


\section{KESIMPULAN}

Kesehatan sangat penting bagi manusia, karena tanpa kesehatan yang baik, setiap manusia akan sulit dalam melaksanakan aktivitasnya sehari-hari. Salah satu cara agar kesehatan tetap terjaga dengan baik adalah melalui olahraga. Partisipasi masyarakat dalam melakukan kegiatan olahraga semakin meningkat yang ditunjukkan dengan peningkatan partisipasi masyarakat pada indeks pembangunan olahraga (SDI). Peran olahraga dalam mendukung terciptanya sumber daya manusia yang memiliki kualitas fisik yang baik sudah tidak diragukan lagi. Selain bermanfaat untuk jasmani, olahraga juga berperan dalam pengembangan karakter bangsa. 


\section{DAFTAR PUSTAKA}

Ade Truna. (2010). Penyebab Malas Olahraga. Diakses dari: http:// adecheeruna.wordpress.com/kesehatan/penyebab-malas-olahragal, tanggal 20 Mei 2013.

Direktorat Keolahragaan. (1987). Buku Petunjuk Penggerak Olahraga Tingkat Desa: Memasyarakatkan Olahraga dan Mengolahragakan Masyarakat. Jakarta Depdikbud.

Farhan. (2011). Olahraga Berperan Tingkatkan Kualitas SDM. Diakses dari: http://www.garutkab.go.id/pub/news/plain/6305-olahraga-berperan-tingkatkankualitas-sdm/, tanggal 7 Mei 2013.

Kusnan. (2013). Olahraga dalam Membangun Kualitas Sumber Daya yang Sehat dan Bugar. Diakses dari: http://www.stkippgrismp.ac.id/olah-raga-dalam-membangunkualitas-sumber-daya-yang-sehat-ketahanan-tubuh-terhadap-penyakit-danbugarl, tanggal 7 Mei 2013.

Menpora RI. (2010). Rencana Strategis Kementerian Pemuda dan Olahraga Tahun $2010 \pm$ 2014. Jakarta: Kemenpora RI.

Sekretaris Kemenpora RI. (2010). Penyajian Data dan Informasi Statistik Keolahragaan Tahun 2010. Jakarta: Kemenpora RI.

Siti Kosasih. Pedoman Strategi Kebijakan Pengarusutamaan Pemuda dan Olahraga. Diakses dari: http://www.academia.edu/5122647/PEDOMAN_STRATEGI _KEBIJAKAN_PENGARUSUTAMAAN_PEMUDA_DAN_OLAHRAGA, tanggal 20 Mei 2013.

Thai Health Promotion Foundation. Physical Activity and Sport for Health. Diakses dari: http://en.thaihealth.or.th/plans/exercise.

VicHealth. (2010). Participation in Physical Activity. Australia: Victorian Health Promotion Foundation.

Zulkarnaen. (2010). Hubungan Motivasi dengan Partisipasi Masyarakat dalam Melakukan Aktivitas Olahraga Futsal di Kota Bekasi. Jurnal MOTION, Volume I. No. 1. September 2010.

Health.detik.com. Rendahnya Kesadaran Masyarakat Indonesia Akan Pentingnya Olahraga. Diakses dari:http://www.cantikdansehat.net/rendahnya-kesadaranmasyarakat-indonesia-akan-pentingnya-olahraga-2/, tanggal 20 Mei 2013. 